\title{
Hepatoprotective, Antioxidant and Cytotoxic Potential of Aloe niebuhriana Latex Extract from Yemen
}

\begin{abstract}
B. A. MOHARRAM*, A. A. AL-DOAISS ${ }^{1,2}$, H. M. AL-MAHBASHI ${ }^{3}$, M. A. AL-KAHTANI ${ }^{1}$, M. A. ALFAIFI ${ }^{1}$, SERAG ELDIN I. ELBEHAIRI ${ }^{1,4}$ AND R. SAIF-ALI ${ }^{5}$

Department of Pharmacognosy, Faculty of Pharmacy, Sana'a University, ${ }^{1}$ Department of Biology, College of Science, King Khalid University, Abha, Saudi Arabia, ${ }^{2}$ Anatomy and Histology Department, Faculty of Medicine, ${ }^{3}$ Department of Forensic Medicine and Clinical Toxicology, Faculty of Medicine, Sana a University, ${ }^{4}$ Cell Culture Lab, Egyptian Organization for Biological Products and Vaccines (VACSERA Holding Company), 51 Wezaret El-Zeraa St., Agouza, Giza, Egypt, ${ }^{5}$ Department of Biochemistry and Molecular Biology, Faculty of Medicine, Sana'a University, Sana'a, Yemen
\end{abstract}

\section{Moharram et al.: Biological Activity of Aloe niebuhriana Latex Extract}

\begin{abstract}
The aim of this study was to quantify the total phenolic content of Aloe niebuhriana latex extract and validate its antioxidant, hepatoprotective and cytotoxic activity. The total phenolic content of the extract was estimated spectrophotometrically using Folin Ciocalteu method. The antioxidant activity of the latex extract was determined using 2,2-diphenyl-1-picrylhydrazyl free radical scavenging assay. Paracetamolinduced hepatotoxicity rat model was used to evaluate the hepatoprotective activity of the extract. Cytotoxic effect of Aloe niebuhriana latex extract was screened against breast MCF-7, liver HepG2 and colon HCT116 cancer cell lines using sulphorhodamine $B$ assay. The extract showed high total phenolic content (245.19 mg GAE/g) and strong antioxidant activity (IC50, 19.14 $\mathrm{mg} / \mathrm{ml})$. Aloe niebuhriana extract showed significant decrease in alanine aminotransferase, aspartate aminotransferase and lactate dehydrogenase, as compared to paracetamol-induced hepatotoxicity model. Hepatoprotective potential of Aloe niebuhriana latex extract was significantly $(p<0.05)$ better than that of the control group and silymarin $(100 \mathrm{mg} / \mathrm{kg} / \mathrm{day})$. Results of the study were well supported by the histopathological observations. Aloe niebuhriana latex extract exhibited a weak cytotoxicity effect against MCF-7, HepG2 and HCT-116 cancer cell lines. The present results provided evidence that the plant extract inhibited hepatotoxicity induced by paracetamol, which was possibly mediated via free radical scavenging and/or inhibition of free radical generation.
\end{abstract}

Key words: Aloe niebuhriana, latex extract, antioxidant, hepatoprotective, paracetamol, cytotoxicitiy

Aloe niebuhriana (family Aloeacea) is a species of Aloe plants endemic to Aarbian Peninsula. In Yemen, it is found in Southern part of Tihama and several parts of Taiz including Hajjadah-Al Mafraq road, Albarakani, Addimna road and Annashamah ${ }^{[1]}$. It is locally called as saber and has been traditionally prescribed, similar to Aloe species, for the external treatment of eye and skin conditions and for treating all sorts of stomach problems and liver or spleen enlargement ${ }^{[2]}$. The bioactivity of some Aloe species included good antioxidant, anticancer, antidiabetic, antiseptic, cardiotonic and antiinflammatory and hepatoprotective effects as well as assisting in wounds healing ${ }^{[3-5]}$. The chemical components of the genus Aloe include relatively high level of phenolic compounds, anthraquinones, anthrones, chromones, coumarins, saponins and polysaccharides, which are present in the leaf gel ${ }^{[3]}$.
Hepatic diseases are considered one of the principal threats to public health and they are a problem worldwide ${ }^{[6]}$. Hepatic disease is a damage of cells, tissues, structure or liver function, and among causes of this damage are biological factors (bacteria, virus, and parasites) and some drugs such as paracetamol ${ }^{[6,7]}$. Viral hepatitis is a major health problem in Yemen. Depending on an old study ${ }^{[8]}$, Yemen is considered as a high endemic area according to the World Health Organization classification ${ }^{[9]}$.

A. niebuhriana possessed diverse pharmacological properties and is prescribed for treating liver diseases in

\footnotetext{
This is an open access article distributed under the terms of the Creative Commons Attribution-NonCommercial-ShareAlike 3.0 License, which allows others to remix, tweak, and build upon the work non-commercially, as long as the author is credited and the new creations are licensed under the identical terms
} Indian J Pharm Sci 2020;82(3):514-521 
the Yemeni traditional medicine. Thus, the present study aimed to validate the species for its hepatoprotective potential against paracetamol-induced hepatotoxicity model in Albino rats and as well as its antioxidant and cytotoxic effects. To the best of our knowledge, the phytochemical, hepatoprotective, antioxidant and cytotoxic activity of $A$. niebuhriana have not been investigated yet.

\section{MATERIALS AND METHODS}

The following chemicals, ethanol (96\%, Umco, Eygpt), paracetamol (T\&T, India), silymarin (Uni Pharma, Egypt), vitamin C (Sigma, USA), Tween 80 (Scharlau, Spain), formaldehyde (Winlab, UK), diethyl ether (BDH, UK), 2,2-diphenyl-1-picrylhydrazyl (DPPH, Sigma Aldrich, USA). Alanine transaminase (ALT), alkaline phosphatase (ALP), aspartate amino transferase (AST), albumin (ALB), creatinine, bilirubin, serum lactate dehydrogenase (LDH) and lipid profile such as total cholesterol (TC) and triglycerides (TG) were tested using kits obtained from Architect, USA. Other reagents were of analytic reagent grade.

\section{Plant material:}

The leaves of $A$. niebuhriana were collected from Alabos, Taiz in June 2017 and identified at the Agricultural Research and Extension Authority (AREA), Dammar, Yemen. The voucher specimen of the plants was prepared and deposited in the Pharmacognosy Department, Faculty of Pharmacy, Sana'a University. The voucher number of A. niebuhriana is Anieb 2017.

\section{Experimental animals:}

Mature healthy male Albino rats, weighing 200 $-250 \mathrm{~g}$, were obtained from the animal house of the Faculty of Science, Sana'a University. The animals were housed in polypropylene cages and maintained under standard conditions (12-h light-dark cycle; $25 \pm 3^{\circ}$; $35-60 \%$ humidity) with strict hygienic conditions, and were fed food and water ad libitum. The rats were acclimatized to the laboratory conditions for at least $48 \mathrm{~h}$ before experimentation. All animal experiments were approved by the Institutional Ethical Committee, Faculty of Medicine and Health Sciences, Sana`a University (Approval No.: 01/FPhSana'a/2018).

\section{Plant extraction:}

A. niebuhriana leaves were thoroughly cleaned before latex collection via cutting the fresh leaves and draining them into clean glass dishes for an hour before drying for $2 \mathrm{~d}$. The latex was then extracted separately using ethanol before filtration. The filtrates were dried via a rotary evaporator (Buchi rotavapour R-215; Switzerland) in a water bath (Buchi water bath B-491; Switzerland) at a temperature not exceeding $45^{\circ}$. The percentage of yield for extract $(49.4 \%$ ) was calculated based on initial dry weights. The final dried extract was stored in desiccators for subsequent phytochemical screening and biological activity tests.

\section{Phytochemical screening:}

Chemical tests were performed according to Banu and Cathrine $^{[10]}$ to identify alkaloids, carbohydrates, fixed oils fats, steroids, anthraquinones, phenol, tannins, proteins, saponins, gums, and mucilage compounds. Chemical constituents and their retention factor (Rf) values for each extract of $A$. niebuhriana were identified using thin layer chromatography (TLC) via conventional one-dimensional ascending method using silica gel 60 F254, 20×20 cm (Merck, Germany). TLC was performed as previously described by Wagner and Bladt $^{[11]}$ and Moharram et al. ${ }^{[12]}$.

\section{Total phenolic content:}

Total phenolic content of $A$. niebuhriana was determined by the Foline Ciocalteu reagent assay. The total phenolic content in the extract was expressed as gallic acid equivalents (GAEs) and was measured according to the method described by Shweta et al. ${ }^{[13]}$.

\section{DPPH antioxidant assay:}

The antioxidant activity of $A$. niebuhriana extracts was carried out according to the method described by Moharram et al. ${ }^{[12]}$.

\section{Acute oral toxicity:}

The acute toxicity of the latex extract of $A$. niebuhriana was estimated in albino rats ${ }^{[12,14]}$. In a pilot experiment, 5 groups each of 6 rats each received the tested extract dissolved in water at doses of 500, 1000, 2500, 4000, $5000 \mathrm{mg} / \mathrm{kg}$, respectively. Animals were observed $48 \mathrm{~h}$ for signs of toxicity and number of deaths. Control animals received the vehicle and were kept under the same conditions without any treatments. Signs of toxicity and number of deaths per dose in $48 \mathrm{~h}$ were recorded.

\section{Hepatoprotictive activity in paracetamol-induced liver toxicity model:}

The hepatoprotective effect of $A$. niebuhriana latex 
extract was performed according to Akther et al. ${ }^{[15]}$ and Alam et al. ${ }^{[16]}$. Paracetamol-induced liver toxicity model was established according to Alam et al. ${ }^{[16]}$. Rats were randomly divided into 5 groups each consisting of 6 rats. Group I rats were treated with only distilled water $(1 \mathrm{ml} / \mathrm{kg})$ for $8 \mathrm{~d}$ and served as normal control. Group II rats were first treated with distilled water for $7 \mathrm{~d}$. Group III and IV animals were first treated with A. niebuhriana latex extract 200 and $400 \mathrm{mg} / \mathrm{kg} / \mathrm{d}$, respectively for $7 \mathrm{~d}$. Group $\mathrm{V}$ animals were first treated with silymarin $100 \mathrm{mg} / \mathrm{kg} / \mathrm{d}$ for $7 \mathrm{~d}$ to serve as reference control. Then the animals of groups II, III, IV and V were administered orally paracetamol $3 \mathrm{~g} / \mathrm{kg}$ as a single dose on day 8 to induce hepatotoxicity. Twenty four hours later, blood was obtained through the retro-orbital plexus under light ether anesthesia following that rats were sacrificed. The isolated liver tissues were washed twice with cold normal saline, blotted, dried and then weighed. Relative liver weight was expressed as a ratio of liver weight to body weight. A small portion of tissue was fixed in $10 \%$ formalin for histopathological examination.

\section{Liver function tests:}

Blood samples collected from rats were allowed to clot and the serum was separated by centrifugation at $3000 \mathrm{~g}$ for $15 \mathrm{~min}$. Serum specimens were assessed for liver enzymes such as ALT, AST, ALP, serum LDH, liver protein such as ALB, creatinine, bilirubin and lipid profile with TC and TG. The tests were carried out as per standard kit methods using UV spectrophotometer according to the manufacturers' structure.

\section{Histological examination:}

Fresh portions of the liver from each rat were cut rapidly, fixed in $10 \%$ formalin. The fixed tissues were dehydrated with 70, 80, 90, 95 and $100 \%$ ethanol, cleared with 2 changes of xylene, and impregnated with 2 changes of molten paraffin wax, using an automatic tissue processor (Sakura, Japan). The specimens were embedded and blocked out using an embedding station (Sakura, Japan) and serial sections of (4-5 $\mu \mathrm{m})$ thickness were cut using a microtome (ModelRM2245, Leica, Germany). An autostainer (Model 5020, Leica, Germany) was used for hematoxylin and eosin staining of the sections. The mounted specimens were examined for alterations in the hepatic tissues of each rat under study using optical microscope (Olympus Microscope BP73 with Digital Camera, Japan).

\section{Cytotoxic activity, cell culture:}

Human hepatocellular carcinoma cell line (HepG-2), colorectal adenocarcinoma cell line (HCT116) and breast adenocarcinoma cell line (MCF-7) were obtained from the American type culture collection (ATCC). Cells were maintained in Roswell Park Memorial Institute Media (RPMI-1640) supplemented with penicillin (100 units $/ \mathrm{ml}$ ) and heat-inactivated fetal bovine serum $(10 \% \mathrm{v} / \mathrm{v})$ in a humidified, $5 \%(\mathrm{v} / \mathrm{v}) \mathrm{CO}_{2}$ atmosphere at $37^{\circ[17]}$.

\section{Cytotoxicity assessment:}

Cytotoxicity of A. niebuhriana extract was tested against human tumor cells using sulphorhodamine $\mathrm{B}$ assay (SRB). Healthy growing cells were cultured in a 96 well tissue culture plate $(3000$ cells/well) for $24 \mathrm{~h}$ before the treatment with the tested extract to allow attachment of the cells to the plate. Cells were exposed to different concentrations of the extract, 0.01 , $0.1,1,10,100$ and $1000 \mu \mathrm{g} / \mathrm{ml}$ and untreated cells were used as control. Triplicate wells were incubated with these concentrations for $72 \mathrm{~h}$ and subsequently fixed with trichloroacetic acid (TCA, $10 \% \mathrm{w} / \mathrm{v}$ ) for $1 \mathrm{~h}$ at $4^{\circ}$. After several washings, cells were stained by $0.4 \%(\mathrm{w} / \mathrm{v}) \mathrm{SRB}$ solution for $10 \mathrm{~min}$ in dark. Excess stain was washed with $1 \%(\mathrm{v} / \mathrm{v})$ glacial acetic acid. After drying overnight, the SRB-stained cells were dissolved with Tris- $\mathrm{HCl}$ and the color intensity was measured in a microplate reader at $540 \mathrm{~nm}$. The linear relation between $\%$ viability of each tumor cell line and extract concentrations was analyzed to get the $\mathrm{IC}_{50}$ (dose of the extract which reduces survival to $50 \%$ ) using Sigma Plot 12.0 software $^{[18]}$.

\section{Statistical analysis:}

Statistical analysis was carried out by one-way analysis of variance (ANOVA) using Statistical Package for Social Sciences (SPSS) version 11.5. The values are represented as mean \pm standard error of mean (SEM). Comparison of mean values of different groups treated with extract, toxicant and positive controls were tested by Tukey's multiple comparison test. $\mathrm{P}<0.05$ was considered significant.

\section{RESULTS AND DISCUSSION}

TLC and the chemical tests performed on the latex indicated that $A$. niebuhriana has various bioactive components including alkaloids, carbohydrates, phenolic compounds (tannins, anthraglycosides, 
anthrones, flavonoids), phytosterols, proteins, coumarins and bitter compounds. Components, solvent system and $\mathrm{Rf}$ values of the extract are listed in Table 1. The results showed that TPC of $A$. niebuhriana extract was $245.19 \mathrm{mg} \mathrm{GAE} / \mathrm{g}$ of dried sample (Table 2). A. niebuhriana extract exhibited strong antioxidant activity with $\mathrm{IC}_{50}$ value of $19.14 \mu \mathrm{g} / \mathrm{ml}$ (Table 2).

The results of oral acute toxicity revealed that all examined doses of $A$. niebuhriana latex extract (up to $5000 \mathrm{mg} / \mathrm{kg}$ ) did not produce any demonstrable acute toxic effects (no diarrhea, hematuria, restlessness, uncoordinated muscle movements, respiratory distress) or deaths in all groups of rats during $48 \mathrm{~h}$, except reversible reduction in motor activity that appeared in doses 2500, 4000, $5000 \mathrm{mg} / \mathrm{kg}$. Ultimately, the highest dose of $A$. niebuhriana used for the in vivo hepatoprotective studies was $400 \mathrm{mg} / \mathrm{kg}$.

The effect of ethanol extract of $A$. niebuhriana latex at two dose levels $(200 \mathrm{mg} / \mathrm{kg}$ and $400 \mathrm{mg} / \mathrm{kg}$, po) on serum biochemical markers in paracetamol-induced hepatic damage of rats is shown in Table 3. Acute oral administration of paracetamol caused severe liver damage as indicated by a significant increase in the marker enzymes AST (1855.3 U/1), ALT (2189.5 U/1), $\operatorname{ALP}(282.3 \mathrm{U} / 1, \mathrm{p}<0.05)$ and $\operatorname{LDH}(2127.3 \mathrm{U} / 1, \mathrm{p}<0.05)$, compared to normal control group I of rats (189 U/1, $57.3 \mathrm{U} / 1,223.0 \mathrm{U} / 1$ and $1300.7 \mathrm{U} / 1$, respectively).
The animals treated with $A$. niebuhriana latex extract (200 and $400 \mathrm{mg} / \mathrm{kg}$ ) showed a significant protection against paracetamol-induced toxicity by restoring the levels of AST, ALT, ALP and serum LDH. The extracttreated groups III $(200 \mathrm{mg} / \mathrm{kg})$ and IV $(400 \mathrm{mg} / \mathrm{kg})$ had significantly decreased AST (347.8 U/1 and 240.2 $\mathrm{U} / 1$, respectively) and ALT (130.5 U/1 and 101.0 U/1, respectively) and $\mathrm{LDH}(1738.5 \mathrm{U} / 1, \mathrm{p}<0.05$ and 1487.5 $\mathrm{U} / 1, \mathrm{p}<0.05$, respectively) compared to paracetamoltreated group II. Silymarin at $100 \mathrm{mg} / \mathrm{kg}$ significantly decreased the high levels of AST, ALT and ALP to 542.0 $\mathrm{U} / 1,362.9 \mathrm{U} / 1$ and $185.1 \mathrm{U} / 1$, respectively compared to paracetamol-treated group II.

Paracetamol-treated group II rats showed significant increase in cholesterol $(78.2 \mathrm{mg} / \mathrm{dl}, \mathrm{p}<0.05)$, total bilirubin $(0.25 \mathrm{mg} / \mathrm{dl})$ and direct bilirubin $(0.27 \mathrm{mg} /$ $\mathrm{dl}, \mathrm{p}<0.05)$, and decrease in ALB $(2.8 \mathrm{~g} / \mathrm{dl}, \mathrm{p}<0.05)$ compared to normal control group I rats $(54.3,0.12$, $0.1 \mathrm{mg} / \mathrm{dl}$ and $3.2 \mathrm{~g} / \mathrm{dl}$, respectively). Administration of $A$. niebuhriana latex extract at 200 and $400 \mathrm{mg} /$ $\mathrm{kg}$ significantly decreased cholesterol level (61.5 and $62.9 \mathrm{mg} / \mathrm{dl}, \mathrm{p}<0.05$, respectively), total bilirubin $(0.12,0.13 \mathrm{mg} / \mathrm{dl}$, respectively) and direct bilirubin $(0.1,0.11 \mathrm{mg} / \mathrm{dl}$, respectively) and non-significantly increased ALB (3.01, $3.1 \mathrm{~g} / \mathrm{dl}$, respectively) compared to paracetamol-treated group II rats. Silymarintreated group $\mathrm{V}$ rats significantly $(\mathrm{p}<0.05)$ decreased cholesterol $(61.5 \mathrm{mg} / \mathrm{dl})$, total and direct bilirubin

TABLE 1: TLC INVESTIGATION OF THE LATEX EXTRACT OF A. NIEBUHRIANA

\begin{tabular}{|c|c|c|c|}
\hline Constituent & Solvent system & No. spot & Retention factor values \\
\hline Anthraglycosides & $\begin{array}{l}\text { Ethyl acetate: methanol: Water } \\
\qquad(100: 13.5: 10)\end{array}$ & 3 & $\begin{array}{l}0.27 \\
0.28 \\
0.34\end{array}$ \\
\hline Bitter principles & $\begin{array}{l}\text { Ethyl acetate: methanol: Water } \\
\qquad(100: 13.5: 10)\end{array}$ & 4 & $\begin{array}{l}0.14 \\
0.30 \\
0.42 \\
0.47\end{array}$ \\
\hline Alkaloids & $\begin{array}{l}\text { Ethyl acetate: methanol: Water } \\
\qquad(100: 13.5: 10)\end{array}$ & 2 & $\begin{array}{l}0.22 \\
0.36\end{array}$ \\
\hline Flavonoids & $\begin{array}{l}\text { Ethyl acetate: Formic acid: Glacial acetic acid: water } \\
\qquad(100: 11: 11: 26)\end{array}$ & 4 & $\begin{array}{l}0.17 \\
0.32 \\
0.39 \\
0.42\end{array}$ \\
\hline Saponins & $\begin{array}{l}\text { chloroform: Glacial acetic acid: methanol: Water } \\
\qquad(64: 32: 12: 8)\end{array}$ & 2 & $\begin{array}{l}0.56 \\
0.74\end{array}$ \\
\hline Coumarins & $\begin{array}{l}\text { Diethyl ether: Toluene } \\
\qquad(1: I)\end{array}$ & 2 & $\begin{array}{l}0.23 \\
0.53\end{array}$ \\
\hline
\end{tabular}

TABLE 2: TOTAL PHENOLIC CONTENT AND ANTIOXIDANT EFFECT OF ALOE NIEBUHRIANA LATEX EXTRACT

\begin{tabular}{lcc}
\hline & Total phenolic content $(\mathrm{mg} \mathrm{GAE} / \mathrm{g})$ & $\mathrm{IC}_{50}$ Antioxidant activity $(\mu \mathrm{g} / \mathrm{ml})$ \\
\hline Latex extract & $245.19 \pm 0.24$ & $19.14 \pm 1.0$ \\
Ascorbic acid (control) & - & $3.8 \pm 0.3$ \\
\hline '-' Not determined; GAEs gallic acid equivalents & \\
517 & Indian Journal of Pharmaceutical Sciences & May-June 2020
\end{tabular}


www.ijpsonline.com

TABLE 3: EFFECTS OF ETHANOL EXTRACT OF ALOE NIEBUHRIANA LATEX ON SERUM BIOCHEMICAL PARAMETERS IN RATS TREATED WITH PARACETAMOL

\begin{tabular}{|c|c|c|c|c|c|}
\hline \multicolumn{6}{|c|}{ Rats groups } \\
\hline liver specific variables & $\begin{array}{c}\text { I } \\
\text { (Normal } \\
\text { control) }\end{array}$ & $\begin{array}{c}\text { II } \\
\text { Hepatotoxic control } \\
\text { (only paracetamol) }\end{array}$ & $\begin{array}{c}\text { III } \\
\text { extract }(200 \mathrm{mg} / \\
\mathrm{kg})\end{array}$ & $\begin{array}{c}\text { IV } \\
\text { extract }(400 \mathrm{mg} / \\
\mathrm{kg})\end{array}$ & $\begin{array}{c}\mathrm{V} \\
\text { Silymarin } \\
(100 \mathrm{mg} / \mathrm{kg})\end{array}$ \\
\hline AST (U/l) & $189.0 \pm 17.2$ & $1855.3 \pm 79.8^{\mathrm{a}}$ & $347.8 \pm 68.5^{\text {bc1 }}$ & $240.2 \pm 39.6^{\text {bc1 }}$ & $542.0 \pm 27.2^{b}$ \\
\hline ALT (U/l) & $57.33 \pm 7.0$ & $2189.5 \pm 227.7^{\mathrm{a} 2}$ & $130.5 \pm 48.8^{\mathrm{bc} 1}$ & $101.0 \pm 16.6^{\mathrm{bc} 1}$ & $362.9 \pm 22.8^{b}$ \\
\hline $\operatorname{ALP}(\mathrm{U} / \mathrm{l})$ & $223.0 \pm 20.7$ & $282.3 \pm 11.0^{\mathrm{a} 1}$ & $269.6 \pm 11.4$ & $208.3 \pm 19.0^{\mathrm{b}}$ & $185.1 \pm 10.0^{\mathrm{b}}$ \\
\hline ALB $(g / d l)$ & $3.2 \pm 0.1$ & $2.8 \pm 0.1^{\mathrm{a} 1}$ & $3.0 \pm 0.2$ & $3.1 \pm 0.1$ & $3.3 \pm 0.0^{\mathrm{b} 1}$ \\
\hline Cholesterol (mg/dl) & $54.3 \pm 5.0$ & $78.2 \pm 5.8^{\mathrm{a} 1}$ & $61.5 \pm 3.3^{b 1}$ & $62.9 \pm 2.4^{\mathrm{b} 1}$ & $61.5 \pm 5.6^{\mathrm{b} 1}$ \\
\hline Creatinine (mg/dl) & $0.3 \pm 0.0$ & $0.3 \pm 0.0$ & $0.3 \pm 0.0$ & $0.4 \pm 0.1$ & $0.3 \pm 0.0$ \\
\hline Direct bilirubin (mg/dl) & $0.1 \pm 0.0$ & $0.3 \pm 0.0$ a1 & $0.1 \pm 0.0^{b 1}$ & $0.1 \pm 0.0 \mathrm{~b} 1$ & $0.1 \pm 0.1^{\mathrm{b} 1}$ \\
\hline Total bilirubin (mg/dl) & $0.1 \pm 0.0$ & $0.3 \pm 0.0$ a1 & $0.1 \pm 0.0^{b}$ & $0.1 \pm 0.0^{b}$ & $0.2 \pm 0.2^{\mathrm{b} 1}$ \\
\hline LDH (U/l) & $1300.7 \pm 124.0$ & $2127.3 \pm 139.1^{\mathrm{a} 1}$ & $1738.5 \pm 125.2^{\mathrm{b} 1}$ & $1487.5 \pm 154.6^{\mathrm{b} 1 \mathrm{c} 1}$ & $1995 \pm 0.0$ \\
\hline TG (mg/dl) & $62.3 \pm 7.0$ & $67.6 \pm 4.2$ & $65.2 \pm 5.3$ & $62.2 \pm 8.5$ & $60.5 \pm 5.1$ \\
\hline Initial b. Wt. (g) & $172.2 \pm 11.7$ & $221.5 \pm 13.8$ & $165.5 \pm 13.4$ & $233.2 \pm 17.1$ & $246.9 \pm 30.6$ \\
\hline Final b. wt (g) & $170.5 \pm 12.4$ & $204.8 \pm 22.5$ & $163 \pm 13.8$ & $232.7 \pm 17.2$ & $243.6 \pm 29.2$ \\
\hline Liver wt. (g) & $6.9 \pm 0.2$ & $8.9 \pm 0.6^{\mathrm{a} 1}$ & $5.8 \pm 0.3^{b}$ & $6.9 \pm 0.7^{b}$ & $6.2 \pm 1.1^{\mathrm{b} 1}$ \\
\hline $\begin{array}{l}\text { Relative liver wt. } \\
\text { (Liver wt. / } 100 \mathrm{~g} \text { b. wt.) }\end{array}$ & $4.2 \pm 0.5$ & $4.9 \pm 1.0$ & $3.6 \pm 0.2$ & $3.0 \pm 0.2^{\mathrm{b} 1}$ & $3.0 \pm 0.4^{\mathrm{b} 1}$ \\
\hline
\end{tabular}

Values were expressed as mean \pm SEM $(n=6) ; A S T$ = aspartate amino transferase; ALT = alanine transaminase; ALP = alkaline phosphatase; ALB

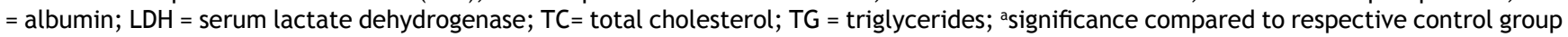
I; 'bsignificance compared to respective control group II; 'significance compared to silymarin; ${ }^{1} \mathrm{p}<0.05$ was considered significant

$(0.15,0.13 \mathrm{mg} / \mathrm{dl}$, respectively) while increased ALB $(3.3 \mathrm{~g} / \mathrm{dl})$ compared to paracetamol-treated group II rats.

Paracetamol-treatment significantly increased the liver weight to $8.9 \mathrm{~g}(\mathrm{p}<0.05)$ compared to the normal control group I ( $6.9 \mathrm{~g})$. Administration of A. niebuhriana extract at doses of 200 and $400 \mathrm{mg} / \mathrm{kg}$ significantly reduced the liver weight (5.75 and $6.96 \mathrm{~g}$, respectively) compared to paracetamol-treated group II rats. Silymarin significantly $(\mathrm{p}<0.05)$ decreased the liver weight to $6.2 \mathrm{~g}$ compared to paracetamol-treated group II rats. The rats treated with $A$. niebuhriana extract $(400 \mathrm{mg} / \mathrm{kg}$ ) and silymarin showed significant $(\mathrm{p}<0.05)$ change in the relative liver weight $(3.0 / 100 \mathrm{~g})$ compared to APAP treated group II rats.

The treatment with A. niebuhriana latex extract at 200 and $400 \mathrm{mg} / \mathrm{kg}$ significantly decreased AST and ALT compared to the reference standard silymarin treated group V rats $(\mathrm{p}<0.05)$. Furthermore, administration of $A$. niebuhriana latex extract at dose $400 \mathrm{mg} / \mathrm{kg}$ significantly reduced LDH compared to reference silymarin treated group $\mathrm{V}$ rats $(\mathrm{p}<0.05)$.

Architecture in the liver of all control rats (GI) demonstrated well preserved and kept intact normal histological components of the hepatic lobules and portal areas. Control rat liver showed normal morphology and absent lesion area, with normal central vein bounded by an intact endothelium. Parallel cords of hepatocytes radiate from the central vein towards the periphery of the hepatic lobule and are separated by sinusoidal spaces (fig. 1A). Microscopic examination of the liver sections in paracetamol-treated animals group exhibited severe centrilobular and coagulative parenchymal necrosis (zone 3), hemorrhage, destruction of central vein (CV) endothelium and marked infiltration of inflammatory (neutrophils) cells (fig. 1B, C).

The liver section of rats pretreated with A. niebuhriana latex extract at doses $200 \mathrm{mg} / \mathrm{kg}$ and $400 \mathrm{mg} / \mathrm{kg}$ showed reversal changes induced by paracetamol. Both doses revealed improvement in the liver architecture and absence of histological alteration (fig. 1D and $\mathrm{E}$, respectively). Meanwhile, the liver section of the animals treated with silymarin showed improvement of liver architecture with some mild degenerative changes in the hepatocytes (fig. 1F). Aloe niebuhriana latex extract exhibited cytotoxic effect against MCF-7, HepG2 and HCT-116 cancer cell lines with $\mathrm{IC}_{50}$ values of $270.4,526$ and $361 \mu \mathrm{g} / \mathrm{ml}$, respectively (fig. 2).

The interest in the therapeutic properties of the Aloe genus has increased dramatically in the recent years. Aloe becomes a component in various healthcare products and cosmetics worldwide. Despite the widespread usage and the recent commercial application of Aloe products, only a few species are currently traded internationally ${ }^{[3]}$.

The present study is the first to report the phytochemical composition of $A$. niebuhriana. This study showed 
that $A$. niebuhriana is rich in phenolic content and has strong antioxidant activity. Phenolic compounds such as chromones, anthrones, anthraquinones, tannin, flavonoids are the most abundant class of phenolic compounds in Aloe leaves ${ }^{[3]}$. Generally, phenolic compounds can scavenge free radicals and neutralize them, preventing human cells from aging process ${ }^{[19]}$. Abnormal production of free radicals in a body leads to cell necrosis and tissue damage ${ }^{[20]}$. Based on the significant pathophysiological role of antioxidation/ detoxification system dysfunction in the development of liver diseases, antioxidant agents can be an effective strategy for fighting oxidative stress that causes liver damage and diseases ${ }^{[21]}$. Therefore, the ability of
A. niebuhriana to act as an antioxidant activity renders this extract to be a hepatoprotective agent.

The present study aimed to assess the hepatoprotective effect of $A$. niebuhriana latex extract against paracetamol-induced liver injury. Paracetamol is an analgesic and antipyretic drug, although, in overdose, it is considered as hepatotoxic agent ${ }^{[22]}$. Paracetamol is widely used in the experimental cell or tissue model of hepatic injury. Paracetamol in overdose causes severe necrosis and infiltration of inflammatory cells initiated by the formation of toxic reactive metabolites $\mathrm{N}$-acetyl-p-benzoquinone imine, which is responsible for liver injury through the depletion of cellular glutathione $(\mathrm{GSH})$ stores $^{[23,24]}$. Paracetamol-induced
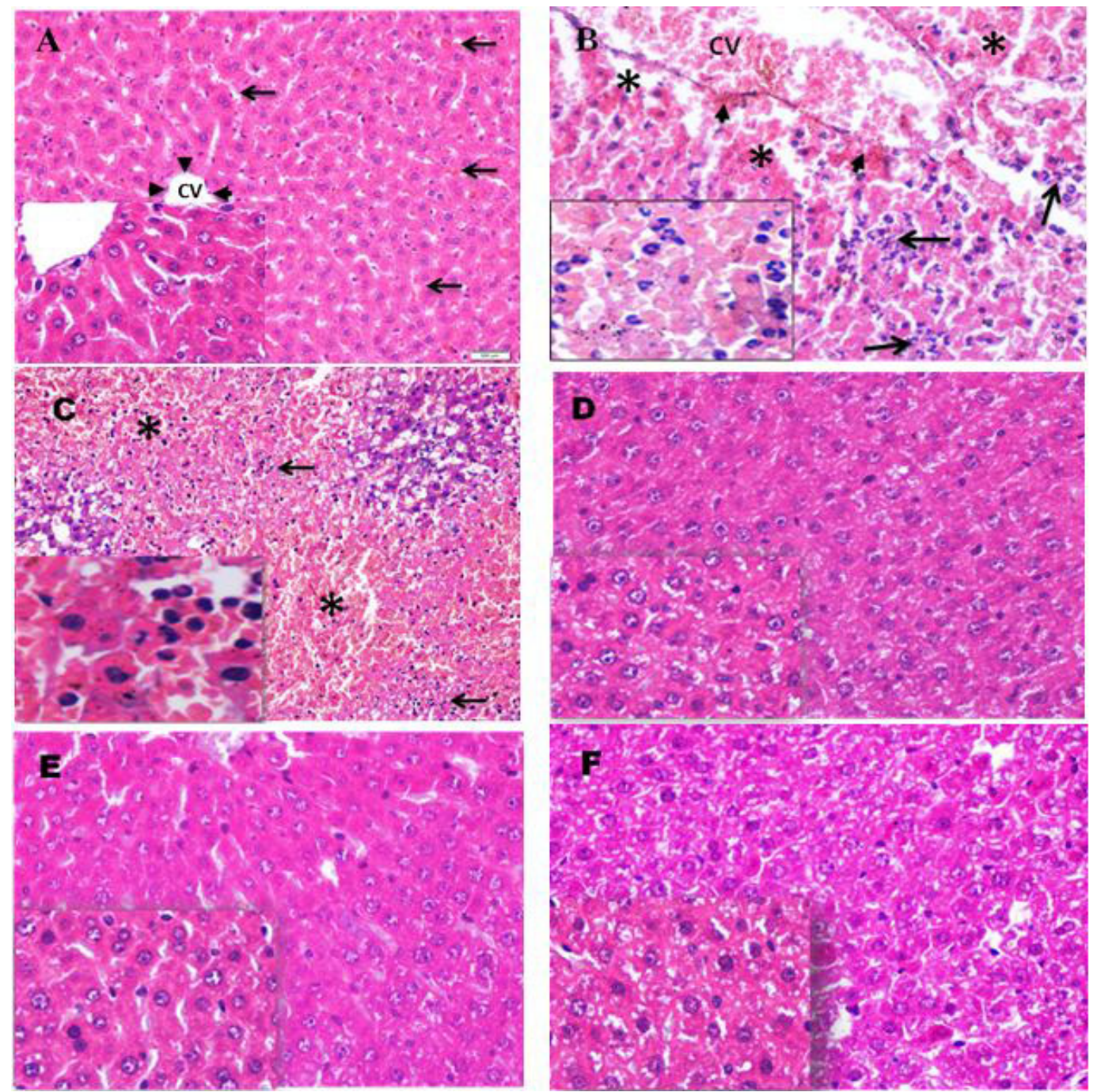

Fig. 1: Representative light micrographs for histopathological changes of effect of treatment with plant extract on the liver tissue morphology

(A) Control rat liver showed normal morphology and absent lesion area, with normal central vein (CV) bounded by an intact endothelium (arrow head). Parallel cords of hepatocytes radiate from the central vein towards the periphery of the hepatic lobule and are separated by sinusoidal spaces (arrows); (B) and (C) paracetamol group: presence of severe necrosis (*), marked inflammatory infiltrate (arrows) and destruction of central vein (CV) endothelium (arrow heads); (D) group treated with plant extract $200 \mathrm{mg} /$ $\mathrm{kg}+$ paracetamol and (E) group treated with plant extract $400 \mathrm{mg} / \mathrm{kg}+$ paracetamol showing improvement of liver architecture with normal hepatic structure; (F) Silymarin+paracetamol, presence of mild lesion area with degenerative changes in hepatocytes. (H \& E; 400X, original magnification). High magnification image inset at the lower left corner of the figures 


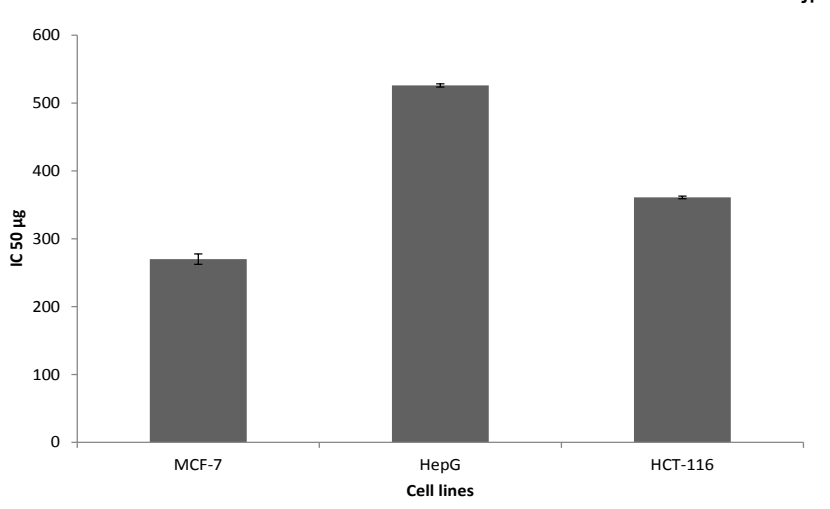

Fig. 2: The $\mathrm{IC}_{50}(\mu \mathrm{g})$ of ethanol extract of Aloe niebuhriana latex against different cancer cell lines

acute liver failure was characterized by elevation of blood chemistry parameters levels in the serum and histopathological changes in the liver ${ }^{[23]}$. The increase in enzyme levels such as AST, ALT, ALP, and serum $\mathrm{LDH}$, bilirubin, albumin, TG, cholesterol and decrease of ALB and total protein have been directly correlated with the severity of hepatic injury ${ }^{[25,26]}$.

In the present study, administration of paracetamol significantly increased the serum levels of AST, ALT, ALP, bilirubin, cholesterol and LDH as a result of liver cell damage indicating the development of hepatotoxicity ${ }^{[27]}$ compared to control. Oral treatment of paracetamol in rats with $A$. niebuhriana latex extract (200 and $400 \mathrm{mg} / \mathrm{kg}$ ) caused a significant restoration of these markers. Similar observations were recorded with the treatment of silymarin $(100 \mathrm{mg} / \mathrm{kg})$, a well-known hepatoprotective natural compound derived from the species Silybum marianum ${ }^{[28]}$. The hepatoprotective and antioxidant activity of silymarin was reported to be caused by controlling free radicals ${ }^{[28]}$, which are obtained by the hepatic metabolism ( $\mathrm{N}$-acetyl-p-benzoquinone imine) of paracetamol. These free radicals, damage cellular membranes and cause lipoperoxidation ${ }^{[29]}$. Silymarin is phenolic in nature which is capable of donating electrons to stabilize free radicals and reactive oxygen species (ROS). Silymarin also affects intracellular GSH, which prevents lipoperoxidation of membranes ${ }^{[30]}$.

This study showed that the treatment of animals with A. niebuhriana latex extract significantly restored the metabolic enzyme activities at both doses, which indicate that they improved the physiological functions of liver. This is the commonly accepted view that serum levels of transaminases return to normal with the healing of hepatic parenchyma and the regeneration of hepatocytes ${ }^{[31]}$.

In the current study, the histological analysis showed an infiltration of neutrophils accompanied with sever necrosis in the livers of the paracetamol-treated rats. Neutrophil-induced damage was probably secondary to necrosis development ${ }^{[32]}$. A. niebuhriana extract treatment significantly improved cellular morphology in both doses, supporting the hepatoprotective action of the extract. This action may be due to antioxidant properties of phenolic content which is found in the present study in a high content as discussed above. Previous study has suggested that the hepatoprotection by Aquilaria agallocha might be due to antioxidant property of the phytochemicals present in the plant which reduced the oxidative stress imposed by paracetamol ${ }^{[15]}$. Another study has reported that A. barbadensis showed hepatoproticitve effect through restoring integrity of hepatocytes indicated by improvement in physiological parameters, excretory capacity of hepatocytes and also by stimulation of bile flow secretion ${ }^{[5]}$.

In current study, A. niebuhriana latex extract exhibited weak activity on MCF-7, HepG2 and HCT-116 cancer cell lines, which was in agreement with recent study that reported negligible toxicity of other Aloe species such as $A$. ferox, A. marlothii and $A$. vera towards the normal human keratinocyte cells $(\mathrm{HaCaT})$ cells $^{[33]}$. In conclusion, the present study shows hepatoprotective activity of $A$. niebuhriana latex against hepatotoxicity induced by paracetamol on rats. This hepatoprotective activity might be due to antioxidant property of phenolic compounds that found in A. niebuhriana latex. Additional phytochemicals works are needed to isolate components responsible for A. niebuhriana activities.

\section{Acknowledgements:}

The authors would like to acknowledge the Microbiology Department of Yemen Lab, Sana'a Yemen; Faculty of Pharmacy, Sana'a University, Yemen; Center of Applied Research and Advanced Studies (CARAS), Faculty of Pharmacy, Cairo University; Biology department, College of Science, King Khalid University, Saudi Arabia. Authors also wish to thank Dr. Abdullah Alnagger, an investigator at Agricultural Research and Extension Authority (AREA), Dammar, Yemen for authenticating the plant material.

\section{Conflict of interests:}

The authors declare that they have no conflicts of interests.

\section{REFERENCES}

1. Al-Khulaidi A. Flora of Yemen. Sustainable Natural Resource Management Project (SNRMP) II. Sana'a, Yemen: 2013. p. 266. 
2. Hehmeyer I, Schönig H. Herbal medicine in Yemen: traditional knowledge and practice, and their value for today's world. Netherlands: Brill; 2012.

3. Cock I. The genus Aloe: phytochemistry and therapeutic uses including treatments for gastrointestinal conditions and chronic inflammation. In: Rainsford K, Powanda M, Whitehouse M, editors. Novel natural products: therapeutic effects in pain, arthritis and gastro-intestinal diseases. Basel: Springer; 2015. p. 179-235.

4. Beatrice A, Nicoletta G, Lorena MPF, Luciano P, Jacopo T, Paola G, et al. Aloe-Emodin Quinone pretreatment reduces acute liver injury induced by carbon tetrachloride. Pharmacol Toxicol 2000;87:229-33.

5. Chandan B, Saxena A, Shukla S, Sharma N, Gupta D, Suri $\mathrm{K}$, et al. Hepatoprotective potential of Aloe barbadensis Mill. against carbon tetrachloride induced hepatotoxicity. J Ethnopharmacol 2007;111:560-6.

6. Madrigal-Santillán E, Madrigal-Bujaidar E, Álvarez-González I, Sumaya-Martínez MT, Gutiérrez-Salinas J, Bautista M, et al. Review of natural products with hepatoprotective effects. World J Gastroenterol 2014;20:14787.

7. Deshwal N, Sharma AK, P. S. Review on hepatoprotective plants. Int J Pharm Sci Rev Res 2011;7:15-26.

8. Guneid AME, Gunaid AA, O'Neill AM, Zureikat NI, Coleman JC, Murray-Lyon IM. Prevalence of hepatitis B, C, and D virus markers in Yemeni patients with chronic liver disease. J Med Virol 1993;40:330-3.

9. Bajubair MA, Elrub AA, Bather G. Hepatic viral infections in Yemen between 2000-2005. Saudi Med J 2008;29:871.

10. Banu KS, Cathrine L. General techniques involved in phytochemical analysis. Int J Adv Res Comput Sci 2015;2:2532.

11. Wagner $\mathrm{H}$, Bladt S. Plant drug analysis: a thin layer chromatography atlas. New York: Springer Science \& Business Media; 1996.

12. Moharram BA, Al-mahbashi HM, Ali RS, Aqlan FA. Phytochemical, anti-inflammatory, antioxidant, cytotoxic and antibacterial study of Capparis cartilaginea decne from Yemen. Int J Pharm Pharm Sci 2018;10:7.

13. Shweta $\mathrm{S}$, Ritesh $\mathrm{T}$, Khadabadi $\mathrm{S}$, Deokate U. In vitro antioxidant activity and total phenolic, flavonoid contents of the crude extracts of Pterospermum acerifolium Willd leaves (Sterculiaceae). J Chem Pharm Res 2010;2:417-23.

14. Al-Mahbashi HM, El-Shaibany A, Saad FA. Evaluation of acute toxicity and antimicrobial effects of the bark extract of Bisham (Commiphora gileadensis L.) J Chem Pharm Res 2015;7:810-4.

15. Akther N, Shawl A, Sultana S, Chandan B, Akhter M. Hepatoprotective activity of Marrubium vulgare against paracetamol induced toxicity. J Pharm Res 2013;7:565-70.

16. Alam J, Mujahid M, Jahan Y, Bagga P, Rahman MA. Hepatoprotective potential of ethanolic extract of Aquilaria agallocha leaves against paracetamol induced hepatotoxicity in SD rats. J Tradit Complement Med 2017;7:9-13.

17. Mahmoud AM, Al-Abd AM, Lightfoot DA, El-Shemy HA. Anti-cancer characteristics of mevinolin against three different solid tumor cell lines was not solely p53-dependent. J Enzyme Inhib Med Chem 2012;27:673-9.

18. Alahdal A, Asfour H, Ahmed S, Noor A, Al-Abd A, Elfaky M, et al. Anti-helicobacter, antitubercular and cytotoxic activities of scalaranes from the red sea sponge Hyrtios erectus. Molecules 2018;23:978.

19. Iqbal E, Salim KA, Lim LB. Phytochemical screening, total phenolics and antioxidant activities of bark and leaf extracts of Goniothalamus velutinus (Airy Shaw) from Brunei Darussalam. J King Saud Univ Sci 2015;27:224-32.

20. Saha S, Verma RJ. Antioxidant activity of polyphenolic extract of Terminalia chebula Retzius fruits. J Taibah Univ Sci 2016;10:805-12.

21. Lv H, Xiao Q, Zhou J, Feng H, Liu G, Ci X. Licochalcone a upregulates Nrf2 antioxidant pathway and thereby alleviates acetaminophen-induced hepatotoxicity. Front Pharmacol 2018;9:147.

22. Sreedevi C, Latha P, Ancy P, Suja S, Shyamal S, Shine V, et al. Hepatoprotective studies on Sida acuta Burm. f. J Ethnopharmacol 2009;124:171-5.

23. Wang L, Wei W, Xiao Q, Yang H, Ci X. Farrerol Ameliorates APAP-induced Hepatotoxicity via Activation of $\mathrm{Nrf} 2$ and Autophagy. Int J Biol Sci 2019;15:788.

24. Bhushan B, Apte U. Liver Regeneration after Acetaminophen Hepatotoxicity: Mechanisms and Therapeutic Opportunities. Am J Pathol 2019;189(4):719.

25. Davidson DG, Eastham WN. Acute liver necrosis following overdose of paracetamol. Br Med J 1966;2:497-9.

26. Agarwal M, Srivastava VK, Saxena KK, Kumar A. Hepatoprotective activity of Beta vulgaris against CCl4induced hepatic injury in rats. Fitoterapia 2006;77:91-3.

27. Gutiérrez RM, Solís RV. Hepatoprotective and inhibition of oxidative stress in liver of Prostechea michuacana. Recf Nat Prod 2009;3:46.

28. Vargas-Mendoza N, Madrigal-Santillán E, Morales-González Á, Esquivel-Soto J, Esquivel-Chirino C, y González-Rubio MG-L, et al. Hepatoprotective effect of silymarin. World J Hepatol 2014;6:144.

29. Trouillas P, Marsal P, Svobodová A, Vostalova J, Gažák R, $\mathrm{Hrbac}^{\sim} \mathrm{J}$, et al. Mechanism of the antioxidant action of silybin and 2, 3-dehydrosilybin flavonolignans: a joint experimental and theoretical study. J Phys Chem A 2008;112:1054-63.

30. Karimi G, Vahabzadeh M, Lari P, Rashedinia M, Moshiri M. "Silymarin", a promising pharmacological agent for treatment of diseases. Iran J Basic Med Sci 2011;14:308.

31. Vadivu R, Krithika A, Biplab C, Dedeepya P, Shoeb N, Lakshmi K. Evaluation of hepatoprotective activity of the fruits of Coccinia grandis Linn. Int J Health Res 2008;1(3):163.

32. Papackova Z, Heczkova M, Dankova H, Sticova E, Lodererova A, Bartonova L, et al. Silymarin prevents acetaminopheninduced hepatotoxicity in mice. PloS One 2018;13:e0191353.

33. Fox LT, Mazumder A, Dwivedi A, Gerber M, du Plessis J, Hamman JH. In vitro wound healing and cytotoxic activity of the gel and whole-leaf materials from selected Aloe species. J Ethnopharmacol 2017;200:1-7. 